\title{
Should Bank Diversify Their Income and Credit? \\ Evidence from Indonesia Banking Industry
}

\author{
Jul Aidil Fadli \\ Faculty of Economics and Business \\ University of Esa Unggul \\ jul.fadli@esaunggul.ac.id
}

\begin{abstract}
This study aims to examine the effect of income and credit diversification toward bank risk and performance. In this study, diversification was measured using Adjusted Herfindahl-Hirschman Index (AHHI). Bank risk is measured by the standard deviation of ROA, standard deviation of ROE, Z-Score, Nonperforming Loan and Beta. Meanwhile, bank performance is measured by Return on Assets, Return on Equity, risk adjusted ROA and risk adjusted ROE. The robustness test completes this study by dividing the sample into low and high diversified bank. By using panel data of 53 listed and non listed Indonesian banks from 2011 to 2015, the results show that banks get benefit through the implementation of income diversification. Conversely, banks are badly affected through the implementation of loan diversification as it can increase risk and decrease bank performance. The results suggest bank to maximize income diversification by increasing the proportion of non-interest income in the income structure. Furthermore, banks should focus credit distribution that best suits their capabilities.

Keywords: bank, credit, diversify, interest income
\end{abstract}

JEL $\quad:$ M14, M38

DOI $\quad: 10.24002 /$ kinerja.v22i2.2124

Received : 1/16/2019 Reviewed: 2/6/2019 Final Version: 2/18/2019

\section{INTRODUCTION}

Research on diversification and its impact on risk and bank performance has received attention from previous researchers (Berger, Hasan, \& Zhou, 
2010; DeYoung \& Roland, 2001; Hayden, Porath, \& Westernhagen, 2007; Hidayat, Kakinaka, \& Miyamoto, 2012; Lepetit, Nys, Rous, \& Tarazi, 2008; Mercieca, Schaeck, \& Wolfe, 2007; Stiroh \& Rumble, 2006). However, the results of previous studies have not produced a crystal consensus. The debate over the impact of banking diversification requires further investigation.

Research on bank diversification has been carried out in developed countries, especially America (DeYoung \& Roland, 2001; Stiroh \& Rumble, 2006) and Europe (Hayden et al., 2007; Lepetit et al., 2008; Mercieca et al., 2007). On the other hand, research on this issue still limited in the context of developing countries. Meslier, Tacneng, \& Tarazi (2014) stated that there are major changes that took place in developing countries such as deregulation and competition thus motivated banks to diversify. Developing countries have unstable financial systems, market structures and regulations that are different from developed countries. These factors led to a different impact on risk and performance if banks enter new business lines.

Research on bank diversification is also related to the measurement of diversification. Previous studies measured diversification with the spread of interest-based income and non-interest income on total operating income (Elsas, Hackethal, \& Holzhäuser, 2010; Hidayat et al., 2012; Mercieca et al., 2007; Stiroh \& Rumble, 2006). Elsas et al. (2010) revealed that the measurement of income diversification is not enough to measure diversification. It takes a more comprehensive measurement both of income and loan, which is the backbone of bank's business, especially in Indonesia.

Recent trends in economic development which are complemented by intense competition and deregulation in the Indonesia banking industry have encouraged banks to diversify sources of income and types of loans offered to customers. Income diversification in Indonesia banking industry has been driven by the application of Bank Indonesia Regulation No. 6/10 / PBI in 2004. Furthermore, market demand tempts banks to offer various types of credit such as commercial loan and consumer loan. This is different from the previous situation, where the bank focused on lending to certain sectors.

The impact of the bank's business diversification still raises questions, especially with the background of Indonesia's growing economy; whether increased profits and decreased risk or otherwise. A number of phenomena and the empirical gap motivate authors to conduct research on the diversification of banking in the context of developing countries, especially Indonesia in the form of income and credit diversification. This study is expected to be the basis for determining the diversification of banking regulations for regulators and the basis of the decision to implement diversification by bank managers. 


\section{LITERATURE REVIEW}

Montgomery (1994) presents three perspectives on corporate diversification motivation; market power view, resource based view, and agency view. The market power view shows that companies diversify because companies have a competitive advantage so they can influence the market (Shepherd, 1970). Meanwhile, resource based view shows that diversification is motivated because the company has excessive resources that must be used productively. Furthermore, the agency view sees that diversification is carried out by the company because of the personal benefits obtained by the manager in implementing the diversification strategy.

Previous literature has not produced a consensus whether banks should diversify or choose to focus. The implementation of diversification strategies can have a detrimental effect on banks in the form of increased supervision costs (Cerasi and Daltung, 2000), reducing profits (Berger et al., 2010), income volatility (DeYoung and Roland, 2001), reducing comparative advantage due to activities outside management capabilities (Klein and Saidenberg, 1998), stimulating competition (Winton, 1999), and increasing agency costs that arise because managers carry out activities that harm the company to achieve their personal benefits (Leaven and Levine, 2007).

A number of empirical evidence shows that diversification can have a negative impact on banks. However, diversification is still chosen by managers in running bank management. Manager's behavior in implementing this diversification strategy can be explained by agency theory that proposed by Jensen and Meckling (1976). Begins with an agency relationship which is defined as a contract where one or more shareholders involve other people (agents) to act and make decisions based on the interests of shareholders. In carrying out the contract, each party is considered as a utility maximizer, so that agents do not always act in the interests of shareholders, but also his personal interests. Through diversification strategies, managers gain personal benefit with reduced risk of failure compared to managers those manage portfolios that are not diversified (Ammihud and Lev, 1981), as well as the recognition of a large company management (Jensen, 1986; Stulz, 1990).

In terms of income diversification, a number of studies also found various benefits from diversification by banks. Elsas et al. (2010) found that income diversification provided benefits by improving bank performance and efficiency. This benefit is obtained by the bank through economic scopes and economies of scale. The existence of a strong relationship between the bank and its customers simplify bank to sell other financial products (product bundling). Lepetit et al. (2008) found that income diversification can increase bank profits because the scope of the broader business activities. In the Indonesian context, previous research conducted by Hidayat et al (2012) 
suggest that income diversification can reduce risk on small banks. Large banks tend to be more aggressive investing in fixed assets to diversify their income, so the risk of failure in banks with large assets tends to be higher. Furthermore, a study conducted by Sianipar (2015) by using sample of listed banks on the Indonesia stock exchange shows that diversification can reduce risk nonsystematic, increase profitability, and reduce cost inefficiency.

Furthermore, credit diversification can increase risk and reduce bank performance. Tabak et al. (2011) that conducted study on Brazilian Bank found that loan portfolio concentration increases returns and also reduces default risk; the impact of concentration on bank's return is decreasing on bank's risk. In Asia, Berger et al. (2010) conducted study in China found that focused banks are associated with higher profits, lower costs, higher profit efficiency, and higher cost efficiency. By diversify their credit, the bank needs a greater supervision cost. Furthermore, credit diversification leaves the bank out of its core competencies so that it fails to mitigate the risks that arise. follows:

Based on a number of literature studies, the hypothesis developed as

$\mathrm{H}_{1}$ : Income diversification has good impact on banks in the form of risk reduction and performance improvement.

$\mathrm{H}_{2}$ : Credit diversification has bad impact on banks in the form of increase risk and reduces performance.

\section{METHODOLOGY}

\subsection{Data and Sample}

The populations in this study are commercial banks operating in Indonesia, both of listed and not listed at Indonesia Stock Exchange. The sample in this study was determined by purposive sampling based on criteria as follows; commercial banks that publish annual reports in 2011 and 2015, commercial banks that diversify their income and credit. We also do not include banks that have data less than 3 years into the sample of this study. The number of banks sampled in this study were 53 banks selected based on the availability of data needed.

Unbalanced panel data is used in this study because banks that are sampled have different data availability between the study periods. The use of panel data is able to capture the assumptions of heterogeneity of individuals or companies to be studied. In addition, panel data is also able to provide variability and more information about the variables under study. Data panel is also able to capture information about individual changes were examined from time to time (Baltagi, 2013) as well as robust to violations of the assumptions of 
normality (Wooldrige, 2013). Overall, the study uses a time period of 5 years (2011-2015). The data used in this study is secondary data obtained from Orbis Bank Focus and related bank's annual reports.

\subsection{Measurement of Variables}

We used two dependent variables namely performance and risk and two independent variables namely income and credit diversification. The operational definition and measurement of the variables used are as follows.

\subsubsection{Risk}

In this study risk is defined as the losses faced in the form of profit volatility and probability of failure faced by banks. The risk is measured by DSROA and DSROE which is the standard deviation of annual ROA and ROE ( $t, t-1, t-2)$. The higher the value of DSROA and DSROE, the higher the risk of volatility faced by banks. This measurement refers to an earlier study conducted Barry, Lepetit, and Tarazi (2011); Saghi-Zedek (2016); Setiyono \& Tarazi (2014). Moreover, the risk faced by the bank failure is measured by Z-score. A low Zcore score indicates a high probability of failure, vice versa. This measurement refers to previous research conducted by Saghi-Zedek (2016) with the following formula:

$$
\text { Zscore }=\frac{\text { ROA+ETA }}{\text { DSROA }}
$$

$$
\begin{array}{ll}
\text { Z-Score } & \text { : risk of bank failure } \\
\text { ROA } & \text { : return on assets } \\
\text { ETA } & \text { : ratio of equity to total assets } \\
\text { DSROA } & \text { : standard deviation of return on assets }
\end{array}
$$

The effect of diversification on credit risk proxied by NPL also tested in this study. A high NPL value indicates the high credit risk faced by banks, and vice versa. We also examine the effect of diversification on Beta to measure the volatility of bank stocks compared to market volatility. This test is only performed on the banks listed on the Stock Exchange.

\subsubsection{Performance}

Bank performance is defined as the ability of banks to generate profits. In this study performance is measured using ROA (Return On Assets) which is the ratio of earnings before tax to total assets, ROE (Return On Equity) which is the ratio of earnings before tax to total equity, RAROA (Risk Adjusted Return on 
Assets) which is ratio of ROA to DSROA, and RAROE (Risk Adjusted Return on Equity) which is ratio of ROE to DSROE.

\subsubsection{Income Diversification}

Income diversification is measured by the Adjusted Hirshcmann-Herfindahl Index $(\mathrm{AHHI})$ which refers previous studies conducted by Acharya, Hasan, Saunders, 2016; Elsas et al., 2010; Saghi-Zedek, 2016; Stiroh, 2004 with the following formula:

$\begin{array}{ll} & \text { DIVINC }=\left(1-\left(\left(\frac{\mathrm{II}}{\mathrm{TOI}}\right)^{2}+\left(\frac{\mathrm{NII}}{\mathrm{TOI}}\right)^{2}\right)\right) \times 100 \% \\ \text { DIVINC } & : \text { income diversification } \\ \text { II } & : \text { interest income } \\ \text { NII } & : \text { non-interest income } \\ \text { TOI } & : \text { total operating income }\end{array}$

\subsubsection{Credit Diversification}

Credit diversification is measured by Adjusted Hirshcmann-Herfindahl Index $(\mathrm{AHHI})$ which refers to a measurement in an earlier study conducted Acharya et al., (2016) and Berger et al. (2010) with the following formula:

$$
\text { DIVLOAN }=\left(1-\left(\left(\frac{\text { COMLOAN }}{\mathrm{TL}}\right)^{2}+\left(\frac{\text { CONLOAN }}{\mathrm{TL}}\right)^{2}+\left(\frac{\mathrm{OL}}{\mathrm{TL}}\right)^{2}\right)\right) \times 100 \%
$$

$\begin{array}{ll}\text { DIVLOAN } & \text { : credit diversification } \\ \text { COMLOAN } & \text { : commercial loan } \\ \text { CONLOAN } & \text { : consumer loan } \\ \text { OL } & \text { : other loan } \\ \text { TL } & \text { : total loan }\end{array}$

A number of control variables include Size which is the natural logarithm of total assets, ETA which is the ratio of total equity to total assets, and dlisted which is a dummy of listed status on the Indonesia Stock Exchange. Based on the description, the research model used is as follows:

$$
\text { Risk }_{i t} / \text { Performance }_{i t}=\beta_{0}+\beta_{1} \text { Divit }_{i t}+\beta_{2} \text { Size }_{i t}+\beta_{3} E T A_{i t}+\beta_{4} \text { dlisted }_{i t}+\varepsilon_{i t}
$$

\section{RESULT AND DISCUSSION}

\subsection{Descriptive Statistic}

Based on descriptive statistics presented in Table 1, the average standard deviation of ROA is 0.42 and the average standard deviation of ROE is 6.7. Meanwhile, the average NPL is $1.7 \%$ with the highest NPL at $3.74 \%$. The data 
shows that there are no banks in the sample that exceed the threshold for NPL of $5 \%$. The average bank asset sampled is 80.9 trillion rupiah. The largest asset is owned by Bank Mandiri in 2015 with total assets of 910 trillion rupiah and the smallest of assets owned by Royal Bank Indonesia in 2013.

Table 1. Descriptive Statistic

\begin{tabular}{|l|r|r|r|r|r|}
\hline \multicolumn{1}{|c|}{ Variables } & Observation & Mean & Std. Dev. & \multicolumn{1}{c|}{ Min } & \multicolumn{1}{c|}{ Max } \\
\hline Panel A. Independent Variable (Risk) \\
\hline DSROA & 242 & 0,423198 & 0,382731 & 0,022 & 2,124 \\
\hline DSROE & 242 & 6,748285 & 18,55965 & 0,232 & 125,391 \\
\hline ZSCORE & 242 & 65,44122 & 63,40209 & 3,38806 & 284,398 \\
\hline NPL & 246 & 1,701545 & 1,081233 & 0,18 & 3,74 \\
\hline BETA & 131 & 1,464763 & 2,528894 & $-2,042$ & 8,819 \\
\hline Panel B. Independent Variable (Performance) \\
\hline ROA & 261 & 1,753019 & 1,125003 & $-0,741$ & 4,869 \\
\hline ROE & 261 & 13,57745 & 8,345273 & 1,487 & 31,527 \\
\hline RAROA & 242 & 8,606777 & 9,592382 & $-0,368$ & 47,995 \\
\hline RAROE & 242 & 7,396107 & 8,744629 & $-0,298$ & 53,176 \\
\hline Panel C. Independent Variables & \multicolumn{5}{|c|}{} \\
\hline DIVINC & 213 & 15,46985 & 11,80275 & 0,919 & 45,159 \\
\hline DIVLOAN & 219 & 29,66798 & 18,54508 & 0,577 & 54,17 \\
\hline Panel D. Control Variables \\
\hline DLISTED & 263 & 0,501901 & 0,50095 & 0 & 1 \\
\hline ETA & 262 & 13,70968 & 5,438122 & 0,218775 & 25,199 \\
\hline SIZE & 262 & 80,9 & 158 & 0,469 & 910 \\
\hline
\end{tabular}

Note: The size of the company expressed in trillion rupiah

Based on descriptive statistics presented in Table 1, the average standard deviation of ROA is 0,42 and the average standard deviation of ROE is 6,7 . Meanwhile, the average NPL is $1.7 \%$ with the highest NPL at $3,74 \%$. The data shows that there are no banks in the sample that exceed the threshold for NPL of $5 \%$. The average bank asset sampled is 80.9 trillion rupiah. The largest asset is owned by Bank Mandiri in 2015 with total assets of 910 trillion rupiah and the smallest of assets owned by Royal Bank Indonesia in 2013.

The best estimation method is determined for the regression model, whether using fixed effects or random effects. Fixed effect model allows the intercept for each individual (bank) have different values, due to the specific characteristics of each individual (bank). Meanwhile, the random effect model specification it is assumed that each individual or company has a random intercept values differ by cross-sectional and time-series (Gujarati, 2012).

The Hausman test is conducted to test whether random effect (RE) is a better estimation model than fixed effect model (FE). The hypothesis tested is $\mathrm{HO}=\mathrm{RE}$ estimator is better and $\mathrm{Ha}=\mathrm{FE}$ estimator is better. By looking at the distribution $\mathrm{X} 2$ it can be determined whether to accept $\mathrm{Ha}$ or reject $\mathrm{Ha}$. If the probability value of $\mathrm{X}<\alpha$ then $\mathrm{H} 0$ unsupported better model used is the fixed effect, otherwise if the probability of $\mathrm{X} 2<\alpha$ then $\mathrm{HO}$ is accepted and a better 
model used is the random effect. Furthermore, to avoid violations of classical assumptions, multicollinearity testing is carried out between independent variables, while heteroscedasticity prevention conducted by robust options so that the standard error robustness is obtained.

\subsection{Hypothesis Testing}

\subsubsection{The Effect of Income Diversification on Risk and Performance}

The test showed a negative effect of income diversification on standard deviation of ROA (-0.263), standard deviation of ROE $(-0,182)$, and NPL ($0.175)$. Meanwhile, diversification of income can increase Zscore (0.250). The results of this test support the hypothesis formulated previously that income diversification has a good impact on banks in the form of risk reduction. Furthermore, the test proof that income diversification has a positive effect on ROA (0.265) and ROE (1.768), but does not affect risk adjusted ROA and risk adjusted ROE. Based on these results it can be concluded that income diversification can improve bank performance as measured by ROA and ROE.

Table 2. The Effect of Income Diversification on Risk and Performance

\begin{tabular}{|l|ccccc|cccc|}
\hline \multirow{2}{*}{ VARIABLES } & \multicolumn{5}{|c|}{ RISK } & \multicolumn{4}{c|}{ PERFORMANCE } \\
\cline { 2 - 9 } & DSROA & DSROE & ZSCORE & NPL & BETA & ROA & ROE & RAROA & RAROE \\
\hline DIVINC & $-0,263^{* *}$ & $-0,182^{*}$ & $0,250^{* *}$ & $-0,175^{*}$ & 0.426 & $0,265^{* *}$ & $1,768^{* *}$ & 0.484 & 0.41 \\
& $(-2,20)$ & $(-1,69)$ & $(-2,02)$ & $(-1,68)$ & $(-1,13)$ & $(2,02)$ & $(2,36)$ & $(0,57)$ & $(0,79)$ \\
SIZE & & & & & & & & & \\
& 0.15 & 0.162 & -0.0119 & $0,488^{* *}$ & -0.659 & 0.126 & 0.572 & 2.178 & $4,302^{* * *}$ \\
& $(0,26)$ & $(0,29)$ & $(-0,02)$ & $(2,44)$ & $(-1,25)$ & $(0,48)$ & $(0,32)$ & $(1,23)$ & $(3,65)$ \\
ETA & & & & & & & & & \\
& 0.0187 & 0.0168 & 0.0551 & 0.0225 & $-0,158^{* *}$ & 0.00719 & $-0,815^{* * *}$ & -0.106 & -0.0564 \\
& $(0,63)$ & $(0,59)$ & $(1,62)$ & $(1,16)$ & $(-2,40)$ & $(0,24)$ & $(-4,30)$ & $(-0,78)$ & $(-0,54)$ \\
DLISTED & & & & & & & & & \\
& 0.537 & 0.329 & -0.526 & 0.35 & & 0.054 & 1.74 & 3.316 & 1.25 \\
& $(1,06)$ & $(0,85)$ & $(-1,06)$ & $(1,52)$ & & $(0,23)$ & $(1,27)$ & $(1,57)$ & $(0,95)$ \\
CONS & & & & & & & & & \\
& -2.303 & -0.0312 & 2.912 & $-3,446^{* *}$ & $7,545^{*}$ & 0.0675 & 15.39 & -9.039 & $-25,35^{* * *}$ \\
& $(-0,49)$ & $(-0,01)$ & $(0,61)$ & $(-2,28)$ & $(1,79)$ & $(0,03)$ & $(1,11)$ & $(-0,74)$ & $(-2,90)$ \\
N & & & & & & & & & \\
& 203 & 203 & 203 & 200 & 127 & 211 & 211 & 203 & 203 \\
\hline
\end{tabular}

Note: The independent variable in this regression is income diversification (DIVINC) which is expressed in logarithm of income diversification. The level of significance ${ }^{* * *}$, ** and ${ }^{*}$ is $1 \%, 5 \%$ and $10 \%$ respectively.

\subsubsection{The Effect of Credit Diversification on Risk and Performance}

Credit diversification has a positive effect on the standard deviation of $\operatorname{ROA}(0,129)$ and standard deviation $\operatorname{ROE}(0,363)$. Meanwhile, the effect of credit diversification on risk proxied by Z-score shows a negative result (-0.109). These results indicate that credit diversification increases the probability of failure faced by banks. The effect of credit diversification on performance which 
is proxied by ROA, ROE, risk adjusted ROA, and risk adjusted ROE shows that credit diversification has a negative impact on bank performance which is proxied by risk adjusted ROE $(-1.167)$. This result shows that every 1 point natural logarithmic increase will decrease 1.167 risk adjusted ROE.

Table 3 The Effect of Credit Diversification on Risk and Performance

\begin{tabular}{|c|c|c|c|c|c|c|c|c|c|}
\hline \multirow{2}{*}{ VARIABLES } & \multicolumn{5}{|c|}{ RISK } & \multicolumn{4}{|c|}{$\begin{array}{l}\text { PERFORMANCE } \\
\end{array}$} \\
\hline & DSROA & DSROE & ZSCORE & NPL & BETA & ROA & ROE & RAROA & RAROE \\
\hline DIVLOAN & $\begin{array}{c}0,129^{* *} \\
(2,04)\end{array}$ & $\begin{array}{c}0,363^{* * *} \\
(3,66)\end{array}$ & $\begin{array}{l}-0,109^{*} \\
(-1,77)\end{array}$ & $\begin{array}{c}-0,0418 \\
(-0,53)\end{array}$ & $\begin{array}{l}-0,358^{*} \\
(-1,93)\end{array}$ & $\begin{array}{l}-0,199 \\
(-1,45)\end{array}$ & $\begin{array}{l}-1,539 \\
(-1,37)\end{array}$ & $\begin{array}{l}-1,167^{*} \\
(-1,73)\end{array}$ & $\begin{array}{c}-0,393 \\
(-1,28)\end{array}$ \\
\hline SIZE & $\begin{array}{c}0,0582 \\
(0,58)\end{array}$ & $\begin{array}{l}0,249 \\
(0,52)\end{array}$ & $\begin{array}{c}-0,0352 \\
(-0,36)\end{array}$ & $\begin{array}{c}0,351^{\text {** }} \\
(1,97)\end{array}$ & $\begin{array}{c}-0,136 \\
(-0,38)\end{array}$ & $\begin{array}{c}-1,656^{* * *} \\
(-2,90)\end{array}$ & $\begin{array}{c}-11,88^{* * *} \\
(-4,51)\end{array}$ & $\begin{array}{c}2,785^{\star *} \\
(1,98)\end{array}$ & $\begin{array}{c}4,733^{* \star *} \\
(4,15)\end{array}$ \\
\hline ETA & $\begin{array}{c}0,0376^{* *} \\
(2,32)\end{array}$ & $\begin{array}{c}0,0152 \\
(0,65)\end{array}$ & $\begin{array}{c}0,0356^{*} \\
(1,93)\end{array}$ & $\begin{array}{c}0,0223 \\
(1,17)\end{array}$ & $\begin{array}{l}-0,145^{\star *} \\
(-2,38)\end{array}$ & $\begin{array}{l}-0,0177 \\
(-0,78)\end{array}$ & $\begin{array}{c}-1,004^{* * *} \\
(-5,97)\end{array}$ & $\begin{array}{l}-0,103 \\
(-0,75)\end{array}$ & $\begin{array}{l}-0,0602 \\
(-0,59)\end{array}$ \\
\hline DLISTED & $\begin{array}{l}-0,362^{*} \\
(-1,93)\end{array}$ & $\begin{array}{l}0,403 \\
(1,01)\end{array}$ & $\begin{array}{l}0,328^{*} \\
(1,88)\end{array}$ & $\begin{array}{l}0,456^{*} \\
(1,93)\end{array}$ & & $\begin{array}{l}-0,45 \\
(-1,30)\end{array}$ & $\begin{array}{c}-0,0254 \\
(-0,06)\end{array}$ & $\begin{array}{l}3,721^{*} \\
(1,83)\end{array}$ & $\begin{array}{l}1,286 \\
(1,10)\end{array}$ \\
\hline CONS & $\begin{array}{c}-2,325^{\star * *} \\
(-2,79)\end{array}$ & $\begin{array}{l}-2,195 \\
(-0,60)\end{array}$ & $\begin{array}{c}3,743^{* * *} \\
(4,45)\end{array}$ & $\begin{array}{c}-2,772^{* *} \\
(-1,96)\end{array}$ & $\begin{array}{l}5,575 \\
(1,53)\end{array}$ & $\begin{array}{c}15,11^{* * *} \\
(3,52)\end{array}$ & $\begin{array}{c}120,0^{* * *} \\
(6,02)\end{array}$ & $\begin{array}{l}-9,199 \\
(-0,83)\end{array}$ & $\begin{array}{c}-26,41^{* * *} \\
(-3,00)\end{array}$ \\
\hline $\mathrm{N}$ & 209 & 209 & 209 & 206 & 127 & 217 & 217 & 209 & 209 \\
\hline
\end{tabular}

Note: The independent variable in this regression is credit diversification (DIVLOAN) which is expressed in logarithm of credit diversification. The level of significance ${ }^{* * *}$, ${ }^{* *}$ and ${ }^{*}$ is $1 \%, 5 \%$ and $10 \%$ respectively.

\subsection{Robustness Test}

Robustness test conducted by dividing samples into high and low diversification. Median acted as the midpoint of the high and low diversification. High diversification is represented by 1 , whereas low diversification is represented by 0 where. The median for income diversification level is 13.426 while 34.961 is the median for credit diversification. The level of income diversification is denoted by DDIVINC and the level of credit diversification is denoted by DDIVLOAN which is a dummy level of diversification. The robustness test results of the effect of income diversification on risk and bank performance as follows.

Robustness test shows that banks with high income diversification have better performance than banks with low income diversification. The effect of income diversification on risk does not show significant results. This test is robust in testing the effect of diversification of income on performance. 
Table 4. Robustness Test on The Effect of Income Diversification on Risk and Performance

\begin{tabular}{|l|ccccc|cccc|}
\hline \multirow{2}{*}{ VARIABLES } & \multicolumn{5}{|c|}{ RISK } & \multicolumn{5}{c|}{ PERFORMANCE } \\
\cline { 2 - 9 } & DSROA & DSROE & ZSCORE & NPL & BETA & ROA & ROE & RAROA & RAROE \\
\hline DDIVINC & 0.0291 & 0.0329 & 0.0838 & -0.142 & 0.587 & $0.380^{* *}$ & $2.948^{* *}$ & -0.341 & 0.693 \\
& $(0.18)$ & $(0.24)$ & $(0.43)$ & $(-0.90)$ & $(1.08)$ & $(2.02)$ & $(2.57)$ & $(-0.18)$ & $(0.59)$ \\
SIZE & & & & & & & & & \\
& 0.0736 & -0.0405 & -0.147 & $0.426^{* *}$ & -0.570 & $-1.840^{* * *}$ & $-12.51^{* * *}$ & 2.682 & $4.354^{* * *}$ \\
& $(0.51)$ & $(-0.29)$ & $(-0.21)$ & $(2.22)$ & $(-1.23)$ & $(-3.29)$ & $(-3.68)$ & $(1.46)$ & $(3.60)$ \\
ETA & & & & & & & & & \\
& $0.0408^{* *}$ & -0.0191 & $0.0707^{*}$ & 0.020 & $-0.142^{* *}$ & -0.0135 & $-0.973^{* * *}$ & -0.100 & -0.0517 \\
DLISTED & $(2.40)$ & $(-0.63)$ & $(1.90)$ & $(1.15)$ & $(-2.21)$ & $(-0.51)$ & $(-5.26)$ & $(-0.74)$ & $(-0.49)$ \\
& -0.315 & -0.119 & -1.117 & $0.398^{*}$ & & -0.406 & 0.215 & 2.972 & 1.152 \\
CONS & $(-1.57)$ & $(-0.45)$ & $(-1.33)$ & $(1.77)$ & & $(-1.10)$ & $(0.36)$ & $(1.42)$ & $(0.89)$ \\
& $-2.141^{* *}$ & 1.668 & 4.607 & $-3.354^{* *}$ & $7.378^{*}$ & $15.71^{* * *}$ & $118.6^{* * *}$ & -11.33 & $-25.12^{* * *}$ \\
& $(-2.02)$ & $(1.52)$ & $(0.85)$ & $(-2.21)$ & $(1.81)$ & $(3.64)$ & $(4.48)$ & $(-0.86)$ & $(-2.80)$ \\
N & & & & & & & & & \\
& 202 & 202 & 202 & 199 & 126 & 210 & 210 & 202 & 202 \\
\hline
\end{tabular}

Note: The level of significance ${ }^{* * *},{ }^{* *}$ and ${ }^{*}$ is $1 \%, 5 \%$ and $10 \%$ respectively.

Based on the robustness test of the effect of credit diversification on bank risk and performance, the results show that banks with high credit diversification have a greater risk than banks with low credit diversification. This can be seen from the effect of credit diversification on risk proxied by DSROA (0.324), DSROE (0.415), and Z-score (0.319). Meanwhile, the robustness test of the effect of credit diversification on performance shows that banks with high credit diversification have lower performance than banks with low credit diversification. This is indicated by the influence of DDIVLOAN on RAROA (3.209). The robustness test shows robust testing of previous tests where credit diversification increases risk and decreases performance. 
Table 5. Robustness Test on The Effect of Credit Diversification on Risk and Performance

\begin{tabular}{|l|ccccc|cccc|}
\hline \multirow{2}{*}{ VARIABEL } & \multicolumn{5}{|c|}{ RISK } & \multicolumn{4}{c|}{ PERFORMANCE } \\
\cline { 2 - 9 } & DSROA & DSROE & ZSCORE & NPL & BETA & ROA & ROE & RAROA & RAROE \\
\hline DDIVLOAN & $0.324^{* *}$ & $0.415^{*}$ & $-0.319^{*}$ & 0.133 & 0.850 & -0.362 & -0.790 & $-3.209^{*}$ & -1849 \\
& $(1.97)$ & $(1.91)$ & $(-1.80)$ & $(1.25)$ & $(1.10)$ & $(-1.56)$ & $(-0.66)$ & $(-1.82)$ & $(-1.45)$ \\
SIZE & & & & & & & & & \\
& 0.0570 & -0.0816 & -0.0240 & $0.339^{*}$ & $-3.086^{*}$ & $-1.601^{* * *}$ & $-11.20^{* * *}$ & $2.856^{* *}$ & $4.891^{* * *}$ \\
& $(0.55)$ & $(-0.65)$ & $(-0.22)$ & $(1.93)$ & $(-1.90)$ & $(-2.89)$ & $(-3.70)$ & $(2.16)$ & $(4.27)$ \\
ETA & & & & & & & & & \\
& $0.0373^{* *}$ & -0.0188 & $0.0563^{* *}$ & 0.0211 & $-0.226^{* *}$ & -0.0168 & $-1.016^{* * *}$ & -0.0680 & -0.0523 \\
DLISTED & $(2.34)$ & $(-0.67)$ & $(2.53)$ & $(1.09)$ & $(-2.50)$ & $(-0.75)$ & $(-6.01)$ & $(-0.50)$ & $(-0.52)$ \\
& $-0.380^{*}$ & -0.243 & $0.416^{*}$ & $0.369^{*}$ & & -0.436 & -0.127 & $3.692^{*}$ & 1,569 \\
K & $(-1.89)$ & $(-0.88)$ & $(1.82)$ & $(1.70)$ & & $(-1.24)$ & $(-0.25)$ & $(1.72)$ & $(1.38)$ \\
& & & & & & & & & \\
& $-2.093^{* *}$ & $1.853^{*}$ & $3.141^{* * *}$ & $-2.803^{* *}$ & $27.46^{* *}$ & $14.28^{* * *}$ & $111.1^{* * *}$ & -12.09 & $-28.09^{* * *}$ \\
& $(-2.56)$ & $(1.87)$ & $(3.51)$ & $(-1.96)$ & $(2.22)$ & $(3.40)$ & $(4.70)$ & $(-1.19)$ & $(-3.23)$ \\
& & & & & & & & & \\
& 208 & 208 & 208 & 205 & 126 & 216 & 216 & 208 & 208 \\
\hline
\end{tabular}

Note: The level of significance ${ }^{* * *},{ }^{* *}$ and ${ }^{*}$ is $1 \%, 5 \%$ and $10 \%$ respectively

\subsection{Result and Discussion}

The results show that diversification has a good impact on banks in the form of risk reduction and performance improvement. The benefits achieved by banks through economic scopes. Strong relationship between banks and customers facilitate banks to sell other financial products. Income diversification can reduce marketing costs, increase bank efficiency, so that increase bank profits. Although banks invest large funds in fixed assets to increase noninterest income, but this increase in non-interest income has proven to have a good impact on the bank.

The results of this study are supported by previous studies by Lepetit et al. (2008) found that income diversification can increase bank profits because of the wider business scope. In the Indonesian context, previous research conducted by Hidayat et al. (2012) suggest that revenue diversification can reduce risk mainly on small banks by assets. This was triggered by the tendency of large banks to be more aggressive in investing in fixed assets to diversify their income, so that the risk of failure in large banks tended to be higher.

Baele (et al. 2007) who examined banks in Europe in the period 19892004 found that diversification of income reduced risk non-systematically. Low correlation between various sources of income is an important factor to support the benefits of income diversification. Furthermore, Sianipar (2015) study on 
banks listed on Indonesian Stock Exchange indicated that income diversification can reduce bank risk. Maximizing trading activities in banks greatly helps banks to reduce their risk. The results of this study are also in line with Bank Indonesia Regulation No. 6/10 / PBI in 2004 which encourages banks to diversify their income into non-interest income, so that the bank does not only focus on traditional activities.

Banks that focus on lending to certain sectors have a comparative advantage compared to banks that diversify credit. This comparative advantage comes from knowledge of certain sectors so that reduce risk. Although banks gain more income by diversify their credit, these benefits are eroded by the dark side of credit diversification, including the high cost of supervision, a greater loss provision because of the magnitude of the credit risk faced. It also relates to the bank's exit from the competencies it controls. For this reason, the implementation of a focus strategy in lending can provide benefits to the bank.

Acharya, Hasan, \& Saunders (2006) who conducted research on the effect of credit diversification on risk and performance in banks in Italy in the period 1993-1999 found that credit diversification does not guarantee banks will get greater profits and lower risks. In the Asian context, research on the effect of credit diversification on bank performance and risk by Berger et al. (2010) in China show that credit diversification reduces profitability and increases bank risk. This is due to the limited ability of managers to expand new business lines, because banking managers in China are appointed based on proximity to the government. For this reason, in carrying out the bank intermediation function it is better to focus on lending to certain sectors that are in accordance with the expertise and resources they have. This strategy of focusing on lending will bring benefits to the form of increased performance and a decrease in risk of income volatility which in turn encourages bank stability.

\section{CONCLUSION}

Diversification does not always have a good impact on the bank. Income diversification is proven to have an impact on both of bank risk and performance. Income diversification in banks in Indonesia has been driven by the application of Bank Indonesia Regulation No. 6/10 / PBI in 2004. Furthermore, credit diversification has a negative impact on banks, so banks are advised to focus on channeling certain types of credit that are in accordance with their expertise and available resources. The strategy focused on lending is expected to maintain bank stability and improve performance.

The results of this study lead us to one direction. Banks should begin to move away from their traditional activities. The bank no longer focuses on providing financing to the community, but also must be vigorous in conducting trading activities and also businesses that generate fees and trading income. In 
terms of credit, banks that focus on one area of lending will become stable and generate greater profits. Banks must move in the appropriate credit sector in their competence.

Diversification measurements in this study using the Adjusted Hirschman Herfindahl Index, a measurement that is widely used in previous studies. The use of other diversification measurements can be an opportunity for further research. Furthermore, this study does not test the diversification threshold that banks can do. This measurement of the maximum diversification limit is an opportunity that can provide a new view in the banking literature.

\section{REFERENCE}

Acharya, V. V., Hasan, I., \& Saunders, A. 2006. Should Banks Be Diversified? Evidence from Individual Bank Loan Portfolios. The Journal of Business, 79 (3), pp. 1355-1412.

Baele, L., O.D., Jonghe, dan RV. Vennet. 2007. Does the stock market value bank diversification?. Journal of Banking and Finance, 31, pp. 1999-2023.

Barry, T. A., Lepetit, L., \& Tarazi, A. 2011. Ownership structure and risk in publicly held and privately owned banks. Journal of Banking and Finance, 35(5), pp. 1327-1340.

Berger, A. N., Hasan, I., \& Zhou, M. 2010. The effects of focus versus diversification on bank performance: Evidence from Chinese banks. Journal of Banking and Finance, 34(7), pp. 1417-1435.

Cerasi, V., \& Daltung, S. 2000. The optimal size of a bank: cost and benefit of diversification. European Economic Review, 44(9), pp. 1701-1726.

Klein, P., \& Saidenberg, M. 1998. Diversification, Organization, and Efficiency: Evidence from Bank Holding Companies. Federal Reserve Bank of New York.

DeYoung, R., \& Roland, K. P. 2001. Product Mix and Earnings Volatility at Commercial Banks: Evidence from a Degree of Total Leverage Model. Journal of Financial Intermediation, 10(1), pp. 54-84.

Diamond, D. W. 1984. Financial intermediation as delegated monitoring: A simple example. Finance a Uver, 51(11), pp. 693-694.

Elsas, R., Hackethal, A., \& Holzhäuser, M. 2010. The anatomy of bank diversification. Journal of Banking and Finance, 34(6), pp. 1274-1287.

Hayden, E., Porath, D., \& Westernhagen, N. V. 2007. Does diversification improve the performance of German banks? Evidence from individual bank Ioan portfolios. Journal of Financial Services Research, 32(3), pp. 123-140. 
Hidayat, W. Y., Kakinaka, M., \& Miyamoto, H. 2012. Bank risk and non-interest income activities in the Indonesian banking industry. Journal of Asian Economics, 23(4), pp. 335-343.

Lepetit, L., Nys, E., Rous, P., \& Tarazi, A. 2008. Bank income structure and risk: An empirical analysis of European banks. Journal of Banking and Finance, 32(8), pp. 1452-1467.

Laeven, L., \& Levine, R. 2008. Bank Governance, Regulation, and Risk Taking. Cambridge, MA.

Mercieca, S., Schaeck, K., \& Wolfe, S. 2007. Small European banks: Benefits from diversification? Journal of Banking and Finance, 31(7), pp. 1975-1998.

Meslier, C., Tacneng, R., \& Tarazi, A. 2014. Is bank income diversification beneficial? Evidence from an emerging economy. Journal of International Financial Markets, Institutions and Money, 31(1), pp. 97-126.

Montgomery, C. A. 1994. Corporate Diversification. Journal of Economic Perspectives-Volume, 8(3), pp. 163-178.

Saghi-Zedek, N. 2016. Product diversification and bank performance: Does ownership structure matter? Journal of Banking and Finance, 71, pp. 154-167.

Setiyono, B., \& Tarazi, A. 2014. Does diversity of bank board members affect performance and risk? Evidence from an emerging market, pp. 1-41.

Stiroh, K. J. 2004. Diversification in Banking: Is Noninterest Income the Answer? Journal of Money, Credit, and Banking, 36(5), pp. 853-882.

Stiroh, K. J., \& Rumble, A. 2006. The dark side of diversification: The case of US financial holding companies. Journal of Banking and Finance, 30(8), pp. 2131-2161.

Van Rixtel Adrian A. R. J. M., G. G. 2013. Financial crises and bank funding: recent experience in the euro area. BIS Working Papers No 406, No. 406 (March), pp. 1-36. 